\title{
AN ANALYSIS OF SMALLHOLDER FARMERS' SOCIO-ECONOMIC DETERMINANTS FOR INPUTS USE: A CASE OF MAJOR RICE PRODUCING REGIONS IN TANZANIA
}

\author{
Nobeji S. Boniphace, PhD Scholar \\ Institute of Agricultural Information, Chinese Academy of Agricultural Sciences \\ No.12 Zhongguancun South St., Haidian District Beijing, PRC \\ E-mail: nobejie@yahoo.com \\ Nie Fengying, Professor \\ Institute of Agricultural Information, Chinese Academy of Agricultural Sciences \\ No.12 Zhongguancun South St.,Haidian District Beijing, PRC \\ E-mail: niefengying@sohu.com, niefengying@caas.cn \\ Fang Chen, Professor, Economist \\ FAO, Rome, Italy \\ E-mail: cheng.fang@fao.org, chengescg@hotmail.co.uk
}

\begin{abstract}
This study analyzed smallholder farmers' socio-economic determinants for inputs use in major rice producing regions in Tanzania. A sample for the study comprised of 842 rice farming households from five major paddy (rice) producing regions of Mbeya, Morogoro, Shinyanga, Mwanza and Tabora. These sample households were drawn from FAO database extracted from the Tanzania National Panel Survey (2010-2011). Household socioeconomic and farm production information were extracted from the database. Descriptive analyses were used to summarize the collected information. Probit model was used to assess determinants of input use among the farming households. The study found that the probability of using agricultural inputs increase with education level, quantity of crops produced, livestock, farm income while it decrease with total number of livestock and nonfarm income owned by a household. The study also found difference in input use preferences among regions; in Mbeya more use in maize while in Shinyanga more input use in rice. Based on these findings, our study concluded that in order to raise the use of agricultural fertilizer among smallholder farmers, policy makers and development agencies should put more efforts on developing and implementing sustainable strategies such as improving market infrastructure that lead to improved access to input and output markets thereby improving farmers' incomes. Price policies are also important to increase and stabilize farmers' incomes and incentivize use of and investment in improved agricultural technologies such as improved agricultural inputs, seeds and post-harvest management techniques.
\end{abstract}

\section{KEY WORDS}

Agricultural inputs; Smallholder farmers; Probit model; Tanzania.

The performance of African agriculture has been disappointing over many decades. Sub-Saharan Africa is reported as the only region in which per capita agricultural value added has not seen a substantial increase, rather a declining trend on average over the last three decades since 1961 with considerable variation over time and across countries (FAO 2008 cited in Wayo et al., 2011).. This declining per capita food production has resulted in increasing rural poverty, rising food prices, widespread famines and increasing food imports. It is a frustrating to note that the Green Revolution, which has saved many lives in Asia and South America, has bypassed Africa and hunger still prevails on the continent despite the past research and development efforts. Some of the factors hindering agricultural development in Africa include, inter alia, inadequate investment in agriculture, limited access to credit by smallholder farmers, high cost and unavailability of inputs such as fertilizers and improved seeds, inadequate use of modern technologies, inefficient agricultural input markets, and the absence of a conducive policy environment. 
Africa's consumption of modern inputs, particularly fertilizers, is comparatively very low. FAO reported in Wayo et al. (2011), projected that the situation was not going to change much in the short run as Africa was expected to account for less than $3 \%$ of world fertilizer consumption by the end of 2012. The use of improved agricultural inputs in Africa is very low and has remained largely static over the last 25 years; lower input usage are in smallholder food crop and livestock production systems.

Efficient input markets are also crucially important in order to deliver the right product, at the right time, in the right amounts, at a convenient place, and for an affordable price. According to Salami et al. (2010) access to input and output markets are a key precondition for the transformation of the agricultural sector from subsistence to commercial production. Smallholder farmers must be able to benefit more from efficient markets and local-level value- addition, and be more exposed to competition. Salami et al. (2010) reported that more than half of the population in most East African countries lives five hours or more from a market center. As a result of market access problem input use is generally low. Wiggins and Jonathan (2010) indicated that the average application rates of fertilizer for arable crops in East African countries are estimated to be below $30 \mathrm{~kg} / \mathrm{ha} / \mathrm{year}$ which is far less than the world average of $100 \mathrm{~kg} / \mathrm{ha} /$ year.

In response to this low agricultural input use, African Union (AU) member states passed the Abuja declaration with resolutions to increase timely access and raise fertilizer use by farmers to an average of $50 \mathrm{~kg} / \mathrm{ha}$ by 2015 . The declaration intended to increase fertilizer access and usage through elimination of barriers to fertilizer access such as tariffs on fertilizers and fertilizer raw materials. Increased fertilizer use is ought to increase productivity, reduce food insecurity and poverty levels among smallholder farmers (Aloyce at el., 2014).

The low use of fertilizer in Africa can be explained by demand side as well as supplyside factors. Demand for fertilizer is often weak in Africa because incentives to use fertilizer are undermined by the low level and high variability of crop yields on the one hand and the high level of fertilizer prices relative to crop prices on the other (Aloyce et al., 2013). Increased use of inputs (seeds, fertilizers and chemicals) alongside organic soil fertility enhancing practices is crucial in addressing the technical change needed for sustainable smallholder agricultural growth in Africa.

\section{FOOD CROP PRODUCTION AND INPUT USE IN TANZANIA}

About $80 \%$ of 45 million Tanzania's population lives in rural areas and their livelihoods depend on agriculture sector; thus the economy is primarily agricultural with the rural sector dominated by smallholder farmers who depends on rain-fed crop production. Even though agricultural value added in total GDP has decreased from 33 percent in 2000 to 28 percent in 2012, about 75 percent of Tanzania's population is still employed in the sector (as of 2012). From 2001 to 2011, agricultural GDP increased by an average of 4.2 percent which is moderate compared to 6.9 percent growth in total GDP. This increased trend in total GDP is driven mainly by private consumption (i.e. growing population), tourism and mining (URT, 2011; Aloyce et al., 2013 and FAO, 2014). Though the Tanzanian economy has registered consistently strong economic growth over the last decade, yet the growth in the agricultural sector, which makes up 23 percent of GDP, lags behind at 4 percent per annum, according to Government of Tanzania figures. Given the importance of the agricultural sector as a source of income, employment and food security for the vast majority of Tanzania's population, this slow growth has translated into little progress in reducing poverty or improving nutritional status during that time. The proportion of the population below the basic needs poverty line remained at more than 33 percent in 2007 while the rate of chronic malnutrition remained stubbornly high at 35 percent (IFDC, 2012). Tanzania's agriculture remains today a traditional, smallholder production system, even though the modernization of agriculture has been on the political agenda of the Government of Tanzania (GoT) for some time. Moreover, Tanzania's agricultural sector continues to be characterized by low level of 
technologies practices in terms of inputs utilization; agricultural implements or machinery and irrigation facilities to enable both the expansion and intensification of agricultural production.

Tanzania is the second largest rice producer in Eastern, Southern and Central Africa and Rice is the second most important food crop, after maize, and most of the rice consumed is produced in the alluvial lowlands, coastal plains, along bottom valleys of mountains, and land depressions as well as along river-valley basins within the country. It is estimated that over 400,000 hectares are under rice cultivation in various parts of the country (Minot, 2010 and Ebony Consulting International (Pty) Ltd, 2003). The main producing regions include Mwanza, Morogoro, Mbeya, Shinyanga and Tabora. Rice is grown is mainly grown by smallscale farmers who typically cultivate 1 to 5 acres while small irrigation farmers grow about 2 to 2.5ha in an irrigation scheme often initiated and controlled by the government (Minot, 2010 and USAID/COMPETE, 2010). Large-scale commercial rice production is limited to few private farms which emerged following the privatization of the National Agricultural and Food Corporation (NAFCO). To date, there are three large-scale rice irrigation schemes in Mbarali District, namely, Madibira 3,000 ha, Kapunga 3,000 ha and Mbarali 3,200 ha, and a few others at Kilombero and Mtibwa (USAID/COMPETE, 2010). Tanzania's 2011 rice production is estimated at 1,340,000 MT; marginally lower from the record 1,346,000 MT achieved in 2008. Despite the upward trend in domestic production, Tanzania has the potential to increase its rice production through improved yields. Currently the yield for rice is at 15.35tonnes/ha, which is low relative to India (32.6tonnes/ha) and the world average (43.7 tonnes/ha). However, rice accounts for $13 \%$ of all cereals produced and are the second most important grain consumed with per capita consumption of rice increasing from about $14.5 \mathrm{~kg}$ per year in 1999 to approximately 16.5 kilograms per year in 2010 (EUCORD, 2012).

Tanzania's agricultural input intensity is very low, farmers use on average $8 \mathrm{~kg} / \mathrm{ha}$ of fertilizers (below SSA average), and only $5.7 \%$ of rice farmers and $0.7 \%$ of maize farmers use improved seed varieties together with fertilizers and agricultural productivity is low by international standards and her own relative potential as measure by research field tests and on-farm trials and (Minot, 2009 and Todd et al., 2012). Moreover, the 2007 Tanzania's Poverty and Human Development Report revealed that 87 percent of Tanzanian farmers were not using chemical fertilizers; 77 percent were not using improved seeds; 72 percent were not using pesticides, herbicides or insecticides (agricultural inputs), as a result of high costs of agricultural inputs and services (R\&AWG, 2007 as quoted by Salami et al.., 2010). Furthermore, though, from 2008 to 2010, there was a sharp increase in fertilizer use but despite this increase, fertilizer application rate of $19.3 \mathrm{~kg} / \mathrm{ha}$ in Tanzania is still low. In comparison, Kenya and South Africa's fertilizer application rates are $100 \mathrm{~kg} / \mathrm{ha}$ and 120 $\mathrm{kg} / \mathrm{ha}$ respectively. On the other hand, there has been a $25 \%$ improvement in average yields for maize from 1.2 MT/ha in 2008 to $1.5 \mathrm{MT} / \mathrm{ha}$ in 2010. Yields may be even better in the regions such as the Southern highlands where fertilizer use has been more concentrated with the focus of the Government's subsidy program. Then again, yields of $1.5 \mathrm{MT} / \mathrm{ha}$ for maize is far below the potential, which is estimated at 6-7 MT/ha under good agronomic practices and using proper amounts of fertilizer (Todd et al., 2012 and World Bank, 2012). Meanwhile, out of 29.4 million hectares (31 per cent of the total land area) with irrigation potential, only 227490 hectares (less than 1 per cent) are currently under irrigation. Moreover, the usage of modern agricultural inputs is very low; only 15 per cent of all farmers use fertilizers (Todd et al., 2013 and Temu, 2006 as quoted by Denise, 2008) whereby good management and optimal fertilizer use should result in yields of 3.5-4.0 tonnes per hectare.

Profitability analysis have revealed negative or extremely thin gross margins for traditional maize and paddy rice because of the use of local seeds, which respond poorly to fertilizers. Hence, the fertilizer subsidy will not help to increase the productivity of smallholder farmers using local variety seeds. Improving crop profitability requires a comprehensive approach: encouraging smallholders to use both improved variety seeds (such as hybrid maize) and fertilizer as a package. Therefore, in order to halve poverty by 2015 (MDG 1), Tanzania will have to increase its agricultural growth. This will require better use of the country's agricultural potential, which is so far largely untapped. (Denise, 2008). The main food crops in Tanzania are maize, rice, wheat, sorghum/millet, cassava and beans. Tanzania 
could be a major food-exporting country, but so far Tanzania's agricultural potential is largely undeveloped. Only 11 per cent of the total land area suitable for agriculture (about 44 million hectares) is under cultivation, mostly by smallholder farmers. The planted area has been stable for several years, indicating that land expansion has ceased to be a major source of agricultural growth. However, one area that has received a lot of attention is that of input subsidies to promote the use of modern agricultural inputs in an effort to raise crop yields that remain well below the potential of readily available technology (Nancy et al., 2014).

According to Lei and Luc (2012), the Government of United Republic of Tanzania resumed subsidy programme in 2003/2004 which its implementation has been emphasized in National Agricultural Input Voucher Scheme (NAIVS) Scaling up and Scaling down implementation plan from 2007-2013 in 56 districts to increase the production of two of its major staple crops; maize and rice and enhance its national food security following the $2007 / 8$ food crisis(Minot, 2009). The NAIVS program was geographically targeted to areas most suitable for maize and paddy rice production, which are mainly concentrated in the Southern and Northern Highlands and the Western Region, while also taking into account the number of smallholder agricultural households who cultivated less than one hectare of maize or rice. As food prices remained high and volatile in the aftermath of the crisis, the program was expanded in 2009 to 65 districts for a period of three years, with the aim to reach 2.5 million households by 2012(Lei and Luc (2012) and Minot, 2009). The NAIVS input package distributed consisted of three vouchers: 1) one for one $50 \mathrm{~kg}$ bag of urea, 2) one for one 50 $\mathrm{kg}$ bag of Di-ammonium Phosphates (DAP) or two $50 \mathrm{~kg}$ bags of Minjingu Rock Phosphate (MRP) with nitrogen supplement, and 3) one for 10 kilograms of hybrid or open-pollinated maize seeds or 16 kilograms of rice seeds, sufficient for half a hectare of maize or rice. Vouchers for each input had a face value equivalent to 50 percent of the market price of the respective input. The remaining 50 percent was to be paid by the farmers. The central government allocates the vouchers to the target regions, which subsequently distribute it to their districts, which in turn distribute it to the villages in their district. At each level of government a special voucher committee was set up to allocate the vouchers to the lower levels based on the expected demand for inputs using historical production data for maize and rice as well as other related information such as the number of smallholder farmers who grow maize and rice and the average land size per farmer. According to the guidelines given, the Village Voucher Committee (VVC) should select farmers that 1) are able to co-finance the inputs purchased with the voucher; 2) are literate and 3) do not cultivate more than 1 ha of maize and/or rice; with priority to be given to female headed households and households who have used little or no modern inputs on maize or rice over the past 5 years. As such, these criteria reflect the implicit dual objective of the program: 1) increase overall maize and rice output (e.g. by focusing on non-input using, literate farmers who are more likely to have a higher marginal productivity) and 2) increase access to modern inputs among poor and vulnerable smallholders (e.g. by giving priority to female headed households (Lei and Luc (2012).

However, many input needy smallholder farmers do not access the inputs under input subsidy programme such as NAIVS and it has been difficult to identify beneficiaries and non beneficiaries. Our paper builds on previous studies done by Esteban et al., 2011 on crop production and input use patterns in Ghana, Omotayo et al., 2014 on smallholder's farmers' decision agrochemical inputs, Irene, 2007 on use of agro-chemicals farmers in Ghana and Jonathan, 2002 on effect of social capital on fertilizer use. Therefore, in this paper we analyse smallholder farmers' determinants for inputs use in five main paddy (rice) producing regions in Tanzania, and based on the study findings, we draw policy recommendations that would contribute to existing knowledge on enhancing sustainable input use strategies for addressing the low input use among smallholder farmers for improved crop productivity in Tanzania and other rural agricultural based economies. 


\section{RESEARCH METHODOLOGY}

Study Area and Producer Selection. The study area and producer selection has been done based on the findings by Kadigi (2003) and Match Maker Associates Limited (2010), that around $90 \%$ of the rice production is by (subsistence) smallholders and production concentrates in Mbeya, Morogoro, Shinyanga, Mwanza and Tabora regions. Moreover, Mbeya and Morogoro regions have good potential for rice production as they always receive good rain fall while Shinyanga, Mwanza and Tabora rely on rain fed rice production (Nobeji et al., 2014). These regions also produces larger quantity of maize and rice and maize were the targeted crops for increased productivity in the National Agricultural Input Voucher Scheme (NAIVS) Scaling up and scaling down implementation plan from 2007-2013 (Minot, 2009).

Data sources and collection. A sample of 842 households from high rice producing regions (Mbeya, Morogoro, Shinyanga, Mwanza and Tabora) in Tanzania was extracted from data compiled by FAO based on the Tanzania National Panel Survey (NPS) for 2010 -2011 and the variables relating to household socio-economic characteristics were defined and computed.

Data Analysis:

Descriptive Statistics. The study used descriptive analyses such as table, graphs, means and standard deviation to describe distribution of farmers' households according to farm characteristics and productivity.

Econometric Model Estimation Procedure. The study applied a probit model analysis to determine factors that influence input use, assuming that agricultural inputs use follow the same path as farmer's decision to use or adopt any agricultural innovation. This study adopted a methodology similar to that used by Yuan et al., (2010) and Irene (2007) which applied the probit model in analyzing factors affecting farmers' decisions on fertilizer use and assessing the factors of use of agro-chemicals respectively. This study used explanatory variables such as age, household size, gender, education, size of land owned, livestock ownership, quantity of rice produced, annual farm income and non farm income to analyse smallholder farmers' socio-economic determinants for inputs use.

Hence, the study assumed that farmers' decision to use inputs (improved seeds and inorganic fertilizers) is assumed that farmers weigh the expected utility of wealth from inputs use can be represented as $U^{A}(\pi)$, and the expected utility of wealth from none use can be represented as $U^{N}(\pi)$ where $\pi$ represents wealth (net farm returns), and use occurs if $U^{A}$ $(\pi)>U^{N}(\pi)$, if we assume that a farmer is risk neutral. The parameters of this decision are not observable, but can be represented by a latent variable $U(\pi)=1$, if $U^{A}(\pi)>U^{N}(\pi)$ and $U(\pi)=0$ if $U^{A}(\pi)<U^{N}(\pi)$. The superscripts for exposition can be dropped and express the utility of inputs use $U(\pi)$ as related to a set of explanatory variables $X$ as:

$$
U(\pi)=\beta X^{\prime}+\varepsilon
$$

where the dependent variable $U$ is binary: $U$ takes value 1 if use occurred and value 0 if use did not occur, $\beta$ is a vector of parameters, $X$ includes farmer's household socio-economic characteristics and $\varepsilon$ is a random error term. The probability of farmers' using agricultural improved inputs (seeds and fertilizers) is expressed as:

$$
\operatorname{Prob}(U=1 \mid X)=\operatorname{Prob} U^{A}(\pi)>U^{N}(\pi)=\operatorname{Prob}\left(\varepsilon>-\beta X^{\prime}\right)
$$

When $\varepsilon$ has a symmetric distribution, this probability can be expressed as:

$$
\operatorname{Prob}\left(\varepsilon<\beta X^{\prime}\right)=\Phi\left(\beta X^{\prime}\right)
$$

where $\Phi$ is a symmetric cumulative density function, assuming that $\Phi$ is a standard normal cumulative distribution function. 
Empirical Model and Variables Used. According to the various studies on the influence of socio economic factors on technology use (Daniel at el., 2001, Irene, 2007, Yuan, 2010 and Wellington et al., 2013) the Probit model employed the following independent variables; age of the house hold age (HEAD AGE),gender of the household head (HEAD GENDER), size of the household( HOUSEHOLD SIZE), level of education of the house hold head(HEAD EDUCATION), marital status of the household head (HEAD MARITAL), quantity of crop produced ( MAIZE PROD OR PADDY PROD), size of land owned by a house hold( TOTAL LAND), number of livestock owned (TOTAL LIVESTOCK), natural log of annual farm income ( FARM INCOME), natural log annual non-farm income( NON FARM INCOME) and dummies for locations in terms of rural and region are included to test the influence of location on agricultural inputs (improved seeds and inorganic fertilizers) use as indicated on Table 1.

Table 1 - Variables Used in Probit Model and Expected Signs

\begin{tabular}{|c|c|c|}
\hline Variable & Definition and measurement of variables & $\begin{array}{l}\text { Expected } \\
\text { Signs }\end{array}$ \\
\hline Dependent & \multirow{2}{*}{\multicolumn{2}{|c|}{$\begin{array}{l}\text { Total cost used for Inputs (Seed and Fertilizer), zero(1) for cost less or equal to } \\
\text { zero, otherwise is equal to one }(1)\end{array}$}} \\
\hline $\begin{array}{l}\text { Total cost of inputs for used } \\
\text { for (Rice production) }\end{array}$ & & \\
\hline \multicolumn{3}{|l|}{ Independent } \\
\hline Head age & Age of the head of the household head ( in years) & + \\
\hline Head gender & Gender of the household head ( Female $=1$, Male $=0$ ) & $+/-$ \\
\hline Household size & Total number of people in the household ( in numbers) & + \\
\hline Head education & Level of education of the household head ( in years & + \\
\hline Head marital & Marital Status of the household head ( Married or not Married) & $+/-$ \\
\hline Rice produced & Quantity of rice produced ( in kilograms) & + \\
\hline Total land & Total land owned by the household (in hectare) & + \\
\hline Total Livestock & Total number of livestock owned by the house hold household & \\
\hline Farm income & $\begin{array}{l}\text { Total household income accrued from annual sales of crops in } \\
\text { shillings (natural log) }\end{array}$ & + \\
\hline Nonfarm income & $\begin{array}{l}\text { Total household income accrued from nonfarm activities in } \\
\text { shillings (natural log) }\end{array}$ & $+/-$ \\
\hline Dummy Rural & House hold location ( rural $=1$, otherwise $=0$ & + \\
\hline Dummy for Regions & $\begin{array}{l}\text { Household region location ( } 1 \text { for respective } \\
\text { regions(Mbeya,Morogoro,Tabora, Shinyanga or Mwanza) } \\
\text { otherwise }=0 \text { ) }\end{array}$ & $+/-$ \\
\hline
\end{tabular}

\section{RESULTS AND DISCUSSION}

\section{Characteristics Smallholder Rice Farmers:}

House Hold Land Ownership. The results in Figure 1 show that Tabora region had a larger size of 6.5 hectares and 6.8 hectares owned and cultivated by male headed household respectively. Moreover, female headed household in Morogoro region cultivated a smaller land sizes of 0.61 hectare while female headed households in Mbeya region owned a smaller land size of 0.9 hectare than all the studied regions.. This result confirms that $90-99 \%$ of rice production is managed by small-scale farmers with holdings of 0.5 to 3.0 ha of land size each (EUCORD, 2012 and Barreiro-Hurle, 2012). Therefore, male headed households will continue to harvest more agricultural crops than female headed households because the size of land owned by a household is one of the important attributes in crop production and male have advantages on land ownership as compared to female in the study area.

Input use for Rice Production. Figure 2 indicates, in most of the rice producing regions studied application cost for input used for rice production is low and the highest cost of input for rice was in Mwanza region with an average input cost of TZS 1,868. A few number of regions indicated input use on maize production than on rice production, Mbeya region had a high maize input use with an average cost of about TZS 7,003. Therefore, crop production in Tanzania is characterized with low input use especially fertilizer and improved seeds and this is in line with the findings of Minot (2009) on the study of Fertilizer policy and use in Tanzania. Therefore low level of inputs use such as fertilizer and improved rice varieties as observed leads to small volume of produced rice resulting to low productivity. 


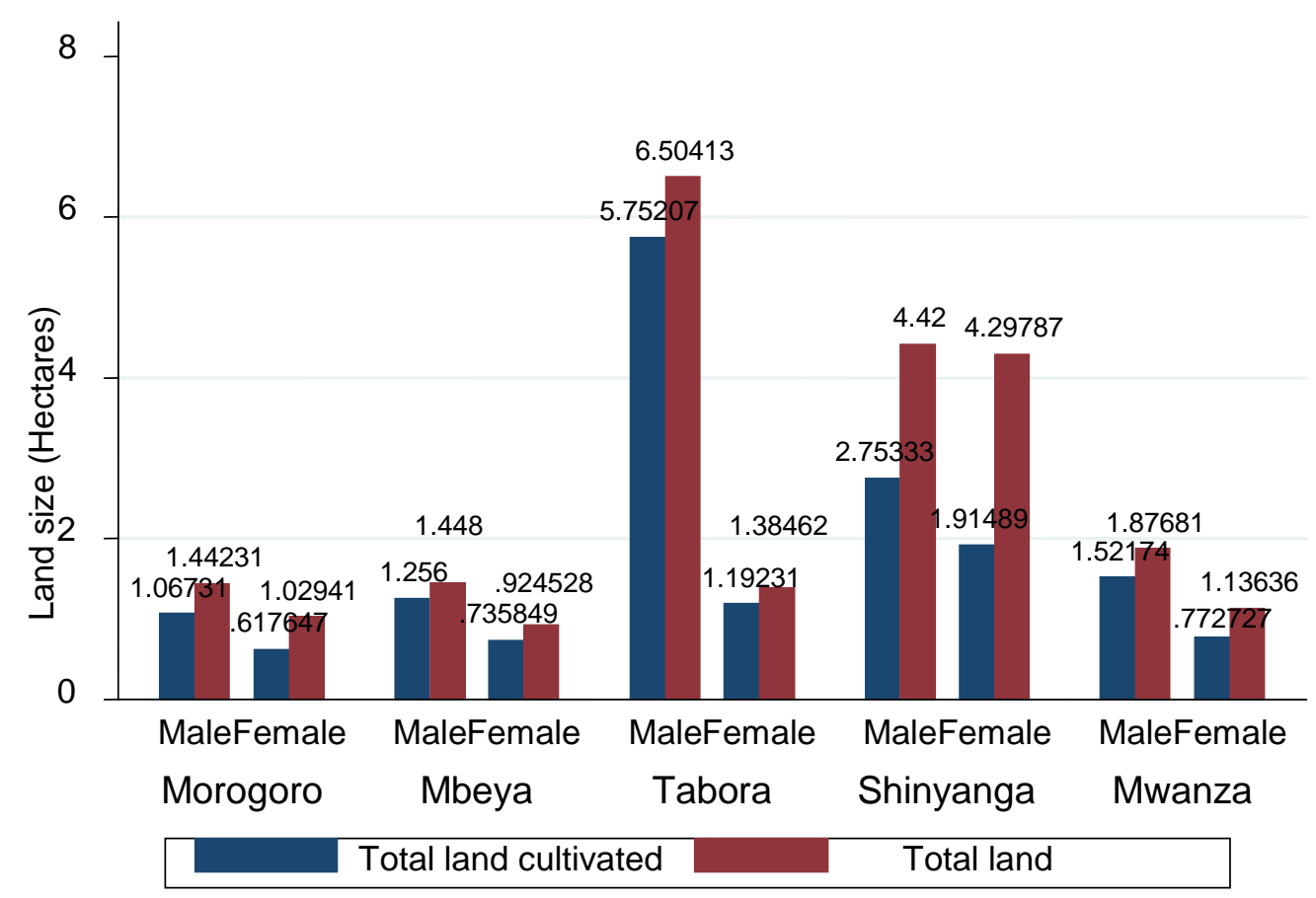

Source: Analysis from NPS, 2010 -2011

Figure 1 - Total arable land distribution by gender and regions

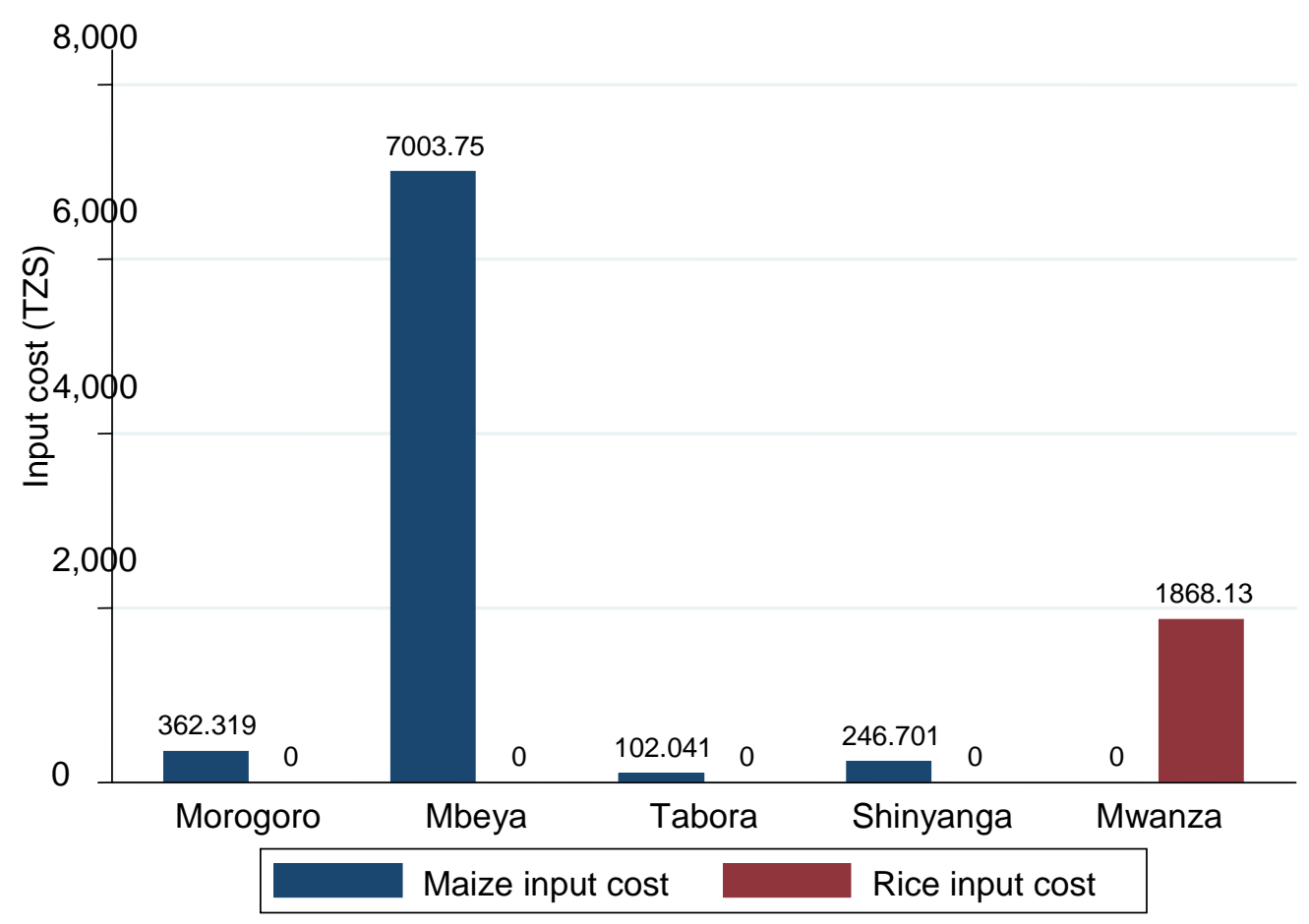

Figure 2 - Cost of input by crops and regions 
Moreover, Rios et al., (2009) found that land ownership is significantly higher in Tanzania, but farm asset ownership and input expenditures are significantly lower. Moreover, this findings on low use of inputs supports the funding by National Bureau of Statistics et al. 2010 , that in 2008, only 9 percent of smallholder farmers in Tanzania regularly used input on their crops though by at present this level may have gone up with the agricultural input subsidy program in place since 2008 to 2013.

Rice production and sales. Based on results in Figure 1show that Shinyanga region has the highest average of rice production and sales for male headed household which were $601.3 \mathrm{Kgs}$ and $291.747 \mathrm{Kgs}$ respectively at the same time female headed household in Tabora region had the lowest amount of rice produced of about $13.7 \mathrm{Kgs}$ and no sold rice. These findings are in agreement with the observation made by EUCORD (2012) and Barreiro-Hurle (2012) that Tanzania's productivity did not change much and varied from 1 to 2.4 MT/ha in 2010 and this low yield is mainly caused by the use of low-yielding varieties, drought, low soil fertility, weed infestations, and the prevalence of insect pests and diseases and birds. Furthermore, variations of volume of rice produced and sales among studied regions can be also associated with other reasons including household resource endowments such as size of land cultivated, levels of farm inputs used, use of improved production techniques and soil fertility (EUCORD, 2012 and Barreiro-Hurle, 2012). Rice sale is affected with house hold size as larger size of household imply that food crops will be required to feed the family first and surplus be sold, availability of sources other sources of income also may discourage the household to sales her crop produce especially food crops for the need of cash.

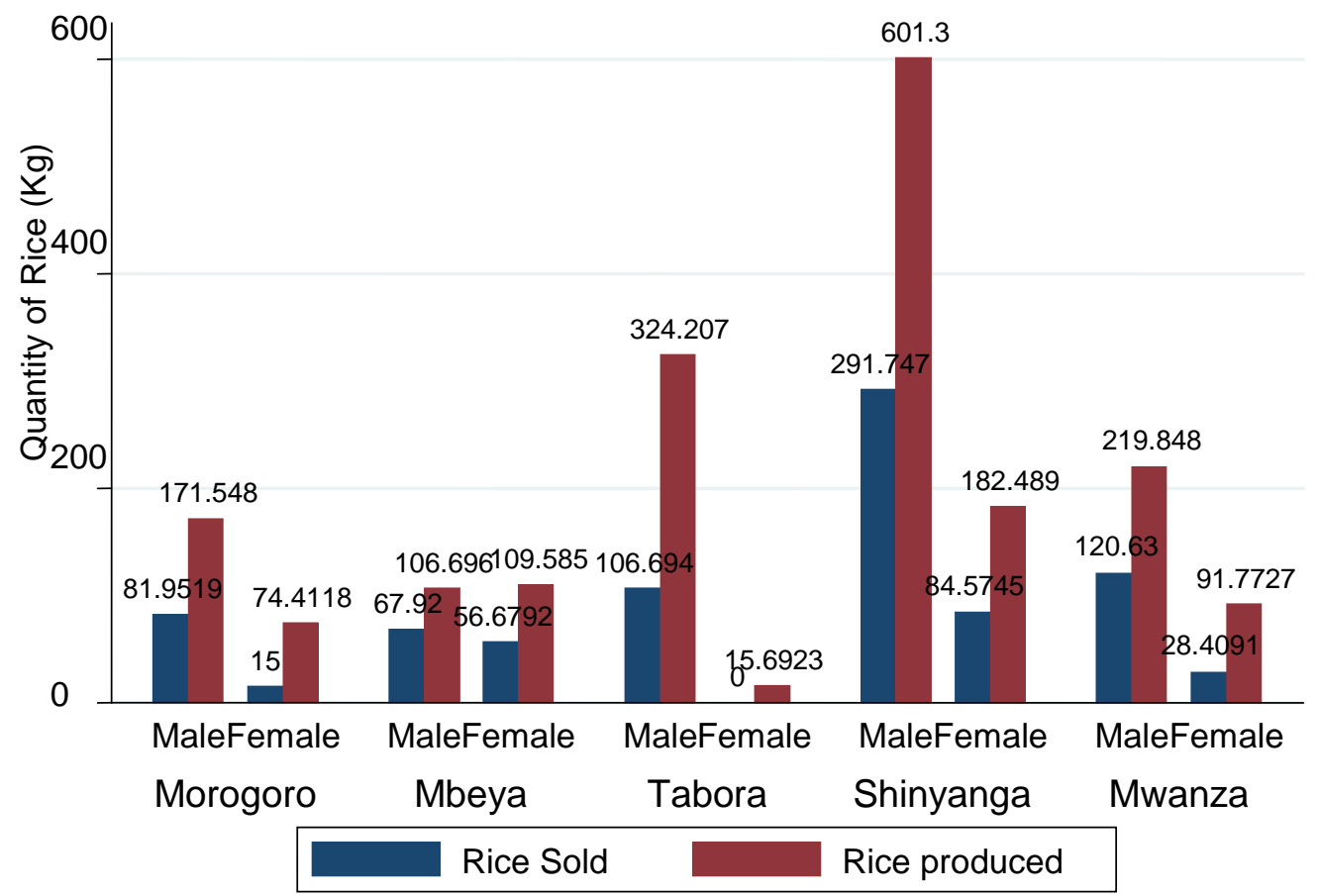

Source: Analysis from NPS, 2010 -2011

Figure 3 - Rice production and sales by region and gender

Livestock ownership. Household livestock ownership indicates more wealth, transportation and animal traction which in turn lead to increased yield and market access. However, ownership of livestock may discourage early crop output market participation because livestock become alternative sources of household income hence discourage early sales of crop produces. The results Figure 4 depicts that Tabora and Shiyanga regions have the larger average of about 19 livestock owned by household while Morogoro region has 
small average of about 6 livestock ownership per household. According to Moti et al., (2009) assets like land, livestock (oxen) farm implements, and human capital are essential for marketable surplus production at a smallholder level. Furthermore, Randela et al., (2008) argued that, ownership of livestock is expected to exert a positive impact on both the likelihood that participation will occur and the amount of selling that will be undertaken once the decision to participate has been made.

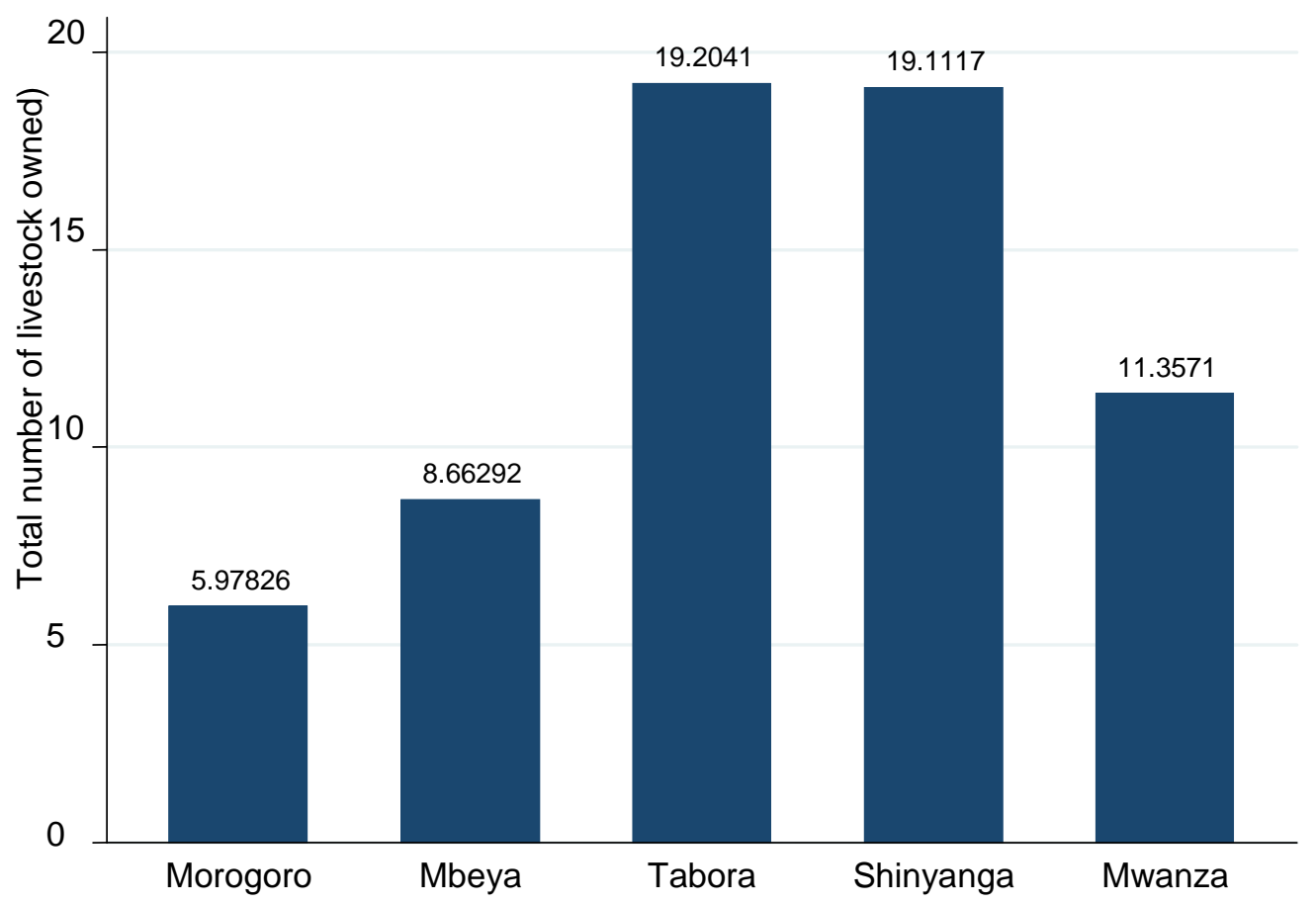

Source: Analysis from NPS, 2010 -2011

Figure 4 - Livestock ownership by regions

Smallholder farmers' sources of income. In this study non-farm income comprised of average annual income from employment wage and remittance from relatives while farm income refers to income accrued from crop sales. The household income access especially from nonfarm activates have influence on market access and may reduce entry barriers. The results in Figure 5 it is also shown that an expectedly, female households in Mbeya region have highest average of TZS 149, 485.00 from nonfarm income. However, all households in the study area indicated low farm income. The lowest average farm income was TZS 2,698.38 and TZS 2,673.83 for female headed households in Mbeya and Tabora regions respectively. This finding presents evidence that higher nonfarm income shares that lead to larger capital endowments (land and assets) may result in higher levels of sales and productivity. Conversely, households with higher nonfarm income share may reduce the time allocated to farm management resulting in lower market participation and lower productivity (Rios at el, 2009). However, various studies on household income have argued that non-farm income is useful in spreading the risk associated with using modern farm technologies. In the sense that, it provides ready cash which smooth household consumption. 


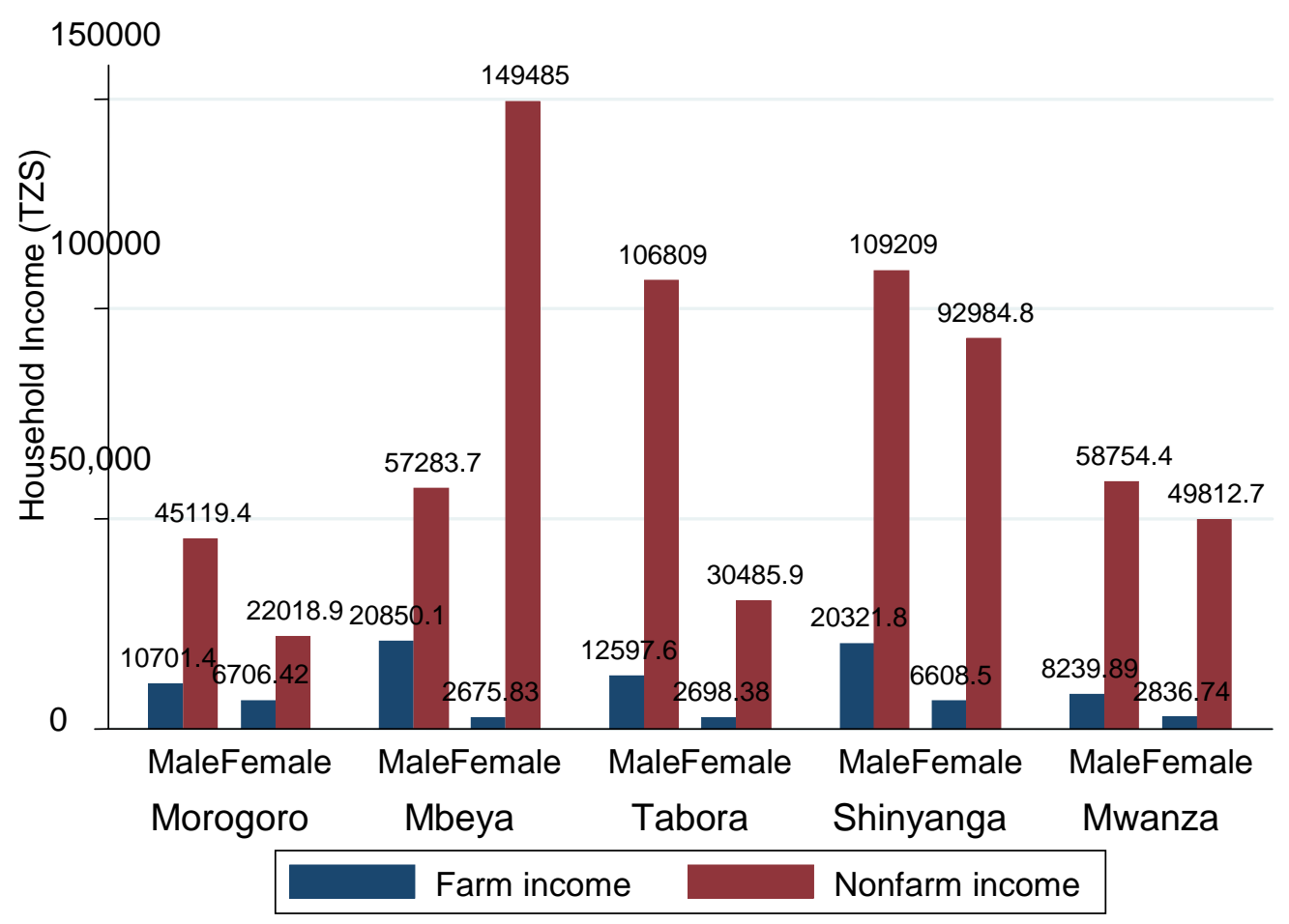

Source: Analysis from NPS, 2010 -2011

Figure 5 - Income sources by gender and region

Results of the Probit model of input use:

With reference to the results in Table 3.2, the Probit model is significant at $p<0.01$ level of probability. The coefficients estimated revealed that there are some factors that influence use of agricultural inputs by smallholder farmers in the study regions. A coefficients that were estimated to be statistically significant, imply that use of agricultural inputs by smallholders' farmers may decrease or increase as the response of the explanatory variable increases/decreases. The findings in Table 3.2 shows that age of the household head, gender of the household head, marital status of the household head and size of land owned by the household were insignificant, meaning that farmers are not likely to be influenced by these variables to make use of agricultural inputs rice production in the study areas.

The coefficient for education level has the expected positive sign and is statistically significant at $p<0.10$ positively influencing smallholder's farmer's use of inputs in rice production. These findings confirm that education has an impact on smallholder farmers' agricultural inputs use. These results are consistent with those reported by Omotayo at el (2014) and Mary at el (2014) supporting the hypothesis that human capital plays a positive role in the acquisition and evaluation of new ideas. Furthermore, programs and materials promoting technological change typically favour literate farmers. The results also indicate that, the coefficient for quantity of rice produced has a positive sign and is statistically significant at $p<0.01$ and positively influencing smallholder's farmer's use of inputs in rice production. Hence, a unit increase of quantity rice produced increases the probability of farmers using input by $0.01 \%$ for rice farmers.

Furthermore, the results indicate that the coefficient for farm income has a positive effect for the utilization of agricultural inputs by smallholder's farmers and is statistically significant at $\mathrm{p}<0.05$ on rice farmers. Implying that, a unit increases in farm income raise the probability of farmers using inputs by $1.9 \%$ for rice. This finding supports the finding by Abdulai and Binder (2006) and Moser and Barret (2003) which suggests that gross farm income from sale of produce is the major source of funds for most farmers, hence the higher income accrued from crop sales the more likely farmers can re-invest part in innovations, suggesting the importance of demonstrating profitability of innovative measures (Tesfaye et al., 2013 and Asamlu 2006). The results also indicate that the coefficient for total number of livestock has a negative effect 
for the utilization of agricultural inputs by smallholder's farmers and is statistically significant at $\mathrm{p}<0.10$ for rice farmers. Implying that, a unit increase in total number of livestock owned by a household decrease the probability of farmers using inputs $0.08 \%$ for rice. These findings are contrary to what Chiputwa et al (2011) and Endale (2010) who found that the use and use of chemical fertilizer in Ethiopia and pointed out that, livestock affects fertilizer use in many ways. The direct effect of livestock is that farmers can sell their livestock and get cash to buy inputs and indirect one is that livestock can serve as collateral for fertilizer credit. However, the findings support the opinion that, intensive animal husbandry may reduce demand for conservation agriculture technologies because crop production is a secondary enterprise hence low investment priority area. Therefore, number of livestock such as cattle may have a positive or negative effect on use of these technologies (Chiputwa et al., 2011).

On the other hand, the results show that, nonfarm income is hypothesized to compensate for any additional financial resources that are associated with new technologies. Moreover, nonfarm income is regarded to be additional income accrued from nonfarm activities which may encourage or discourage investment in new technologies (Gregory and Sewando, 2013). The coefficient for nonfarm income has a positive and negative effect for the use of agricultural inputs by smallholder's maize and rice farmers respectively. For maize farmers, nonfarm income is negative and insignificant. The finding implying the negative and insignificant estimate for rice farmers supports the findings by Tesfaye et al., 2013; Yuan et al., 2010 and Beyene, 2008which could be attributed to the higher relative returns from other nonfarm investments and when nonfarm enterprises have higher returns, then smallholder's farmers might prefer to invest in options that have better returns, given the risk involved in agriculture (Tesfaye et al., 2013; Yuan et al., 2010 and Beyene, 2008).

Furthermore, in assessing the effect of farmers' location on the use of agricultural input, the findings suggests that among the five regions included in the Probit model, Shinyanga region has a positive and significant effect at $p<0.05$ on rice farmers input use. These results indicate that increase in number of farmers located in Shinyanga region raise the probability of farmers to use input on rice production by $3.8 \%$. this results may be due to the fact that, use of input in Shinyanga religion for rice production may be the result of dependence of rain on rice production the lake zone regions especially in Shinyanga region where rice production is mainly rain fed. Hence farmers apply fertilizer on seedlings so that they can grow fast and quickly be transplanted to the field during rainy season.

Table 2 - Results of Probit model estimation

\begin{tabular}{|l|l|l|l|}
\hline \multirow{2}{*}{ Dependants Variables } & \multicolumn{3}{c|}{ Determinants of inputs use in Rice production } \\
\cline { 2 - 4 } & \multicolumn{1}{|c|}{ Coefficient } & \multicolumn{1}{c|}{ P-Values } & \multicolumn{1}{c|}{ Marginal effects } \\
\hline Head age & -0.002 & 0.770 & -0.0001 \\
\hline Head gender & -0.215 & 0.396 & -0.0182 \\
\hline Household size & 0.033 & 0.108 & 0.0031 \\
\hline Head education & 0.0001 & 0.096 & $0.0001^{*}$ \\
\hline Head marital & 0.0669 & 0.185 & 0.0062 \\
\hline Rice produced & 0.0003 & 0.000 & $0.0001^{* * *}$ \\
\hline Total land & -0.0039 & 0.810 & -0.0004 \\
\hline Total Livestock & -0.0082 & 0.068 & $-0.0008^{*}$ \\
\hline Farm income & 0.0521 & 0.019 & $0.0048^{* *}$ \\
\hline Nonfarm income & -0.0094 & 0.499 & -0.0009 \\
\hline Dummy Rural & 0.254 & 0.260 & 0.0211 \\
\hline Dummy Morogoro & 0.2996 & 0.170 & 0.0331 \\
\hline Dummy Mbeya & -0.2277 & 0.342 & -0.0189 \\
\hline Dummy Tabora & -0.3386 & 0.184 & -0.0262 \\
\hline Dummy Shinyanga & 0.039 & $0.0379^{* *}$ \\
\hline Cons & -0.504 & 0.000 & \\
\hline Number of observation & -2.410 & & \\
\hline LR chi2 & 835 & & \\
\hline Log likelihood & 55.69 & & \\
\hline Pseudo R2 & -172.25 & \\
\hline Prob > chi2 & 0.1392 & \\
\hline
\end{tabular}

Note: ${ }^{* * *}$ significant at $p<0.01,{ }^{* *}$ significant at $p<0.05$ and ${ }^{*}$ significant at $p<0.10$ 


\section{CONCLUSION AND RECOMMENDATIONS}

Based on these study findings, it can be concluded that, the probability of using agricultural inputs increases with education level, quantity of rice produced, livestock, farm income and household been located in Shinyanga region for rice, but decreases with total number of livestock and nonfarm income owned by a household. The results further suggest that age of the household head, gender of the household head, and marital status of the household head and size of land owned by the household were insignificant, meaning that farmers are not likely to be influenced by these variables to make use of agricultural inputs in rice production in the study areas. The coefficient for education level has the expected positive sign and is statistically significant and positively influencing smallholder's farmer's use of inputs rice production, confirming that education has an impact on smallholder farmers' agricultural inputs use. Supporting the hypothesis that human capital plays a positive role in the acquisition and evaluation of new ideas because programs and materials promoting technological change typically favour literate farmers.

The quantity of rice produced indicated as positive sign and is statistically significant and positively influencing smallholder's farmer's use of inputs in rice production. Where by farm income has a positive effect for the utilization of agricultural inputs by smallholder's farmers and is statistically, suggesting that gross farm income from sale of produce is the major source of funds for most farmers, hence the higher income accrued from crop sales the more likely farmers can re-invest part in innovations. The coefficient for total number of livestock has a negative effect for using agricultural inputs by smallholder's farmers and is statistically significant for rice farmers, implying that, a unit increase in total number of livestock owned by a household decrease the probability of farmers using inputs. Which does not support the fact that livestock can have can be two effects, the direct effect of livestock is that farmers can sell their livestock and get cash to buy inputs while the indirect one is that livestock can serve as collateral for fertilizer credit. However, it support the fact that, the intensive animal husbandry may reduce demand for conservation agriculture technologies because crop production becomes a secondary enterprise hence it is given low priority for investment when it comes to new innovation. Therefore, number of livestock such as cattle may have a positive or negative effect on use of these technologies.

Moreover, nonfarm (off-farm) income has a negative effect for the use of agricultural inputs by smallholder rice farmers. However, the negative and insignificant estimate for rice farmers could be attributed to the higher relative returns from other nonfarm investments and when nonfarm enterprises have higher returns, then smallholder's farmers might prefer to invest in options that have better returns, given the risk involved in agriculture. Therefore, agricultural income should exceed off-income for farmers to be motivated to invest in the use of agricultural inputs. Furthermore, in assessing the effect of farmers' location on the use of agricultural input, the findings suggests that among the five regions included in the Probit model, Shinyanga region has a positive and significant effect on rice farmers input use. This finding may be due to the fact that, in Shinyanga region rice production is mainly rain fed whereby fertilizer is mainly used for fast tracking the growth of seedling so that transplantation can be done within the short rain season.

Therefore, to raise the use of agricultural fertilizer among smallholder farmers, policy makers and development agencies should put more efforts on developing and implementing sustainable strategies that shall lead to improved access to input and output markets. Through improved market infrastructures and agricultural price policies, by so doing smallholder farmers are likely price incentives that increase their farm income as a result they may lead to investment in improved agricultural technologies such as improved use of agricultural inputs and post harvest management techniques. 


\section{REFERENCES}

1. Abdulai, A.C, and C. Binder (2006). "Slash and Burn Cultivation Practice and Agricultural Input Demand and Output Supply". Journal of Environment and Development Economics, 11(2), 201-220.

2. Aloyce G. M., Gabagambi D. M. and Hella J. P. (2014). Assessment of operational aspects of the input supply chain under national agriculture input voucher scheme (NAIVS) in Tanzania, Journal of Development and Agricultural Economics, Vol. 6(3), pp. 94-104, March, 2014

3. Aloyce S. Hepelwa, Onesmo Selejio and John K. Mduma (2013). The Voucher System and the Agricultural Production in Tanzania: Is the model adopted Effective? Evidence from the Panel Data analysis, available at http://www.efdinitiative.org

4. Amsalu, A., and J. De Graaff (2006). "Determinants of Use and Continued use of Stone 19 Terraces for Soil and Water Conservation in an Ethiopian Highland Watershed". Journal of Ecological Economics, 61(2-3), 294-30.

5. Assa M., A. Mehire, K. Ngoma, E. Magombo and P. Gondwe (2014) Determinants of Smallholder Farmers' Demand for Purchased Inputs in Lilongwe District, Malawi: Evidence from Mitundu Extension Planning Area, Middle-East Journal of Scientific Research 19 (10): 1313-1318, 2014

6. Beyene, $A D$ (2008). Determinants of Off Farm participation decision of farm households in Ethiopia, Agrekon, Vol 47, No 1 (March 2008)

7. Chiputwa, Brian, Augustine S. Langyintuo and Patrick Wall (2011). Use of Conservation Agriculture Technologies by Smallholder Farmers in the Shamva District of Zimbabwe: A Tobit application, the 2011 meeting of the Southern Agricultural Economics Association (SAEA) in Texas, USA, Feb 5-8

8. Daniel C. Clay,Valerie Kelly,Edson Mpyisi, and Thomas Reardon (2001). Input Use and Conservation Investments among Farm Households in Rwanda: Patterns and Determinants, available at http://ageconsearch.umn.edu/handle/57053

9. Denise Wolter (2008). Business development; The Challenge of Moving from Subsistence to Profit in Tanzania, available at www.oecd.org/dev/publications/businessfordevelopment

10. Ebony Consulting International (Pty) Ltd (2003). Development Alternatives Inc, Private Enterprise Support Activities Project Tanzania, Prepared under USAID contract no. PCEI-00-99-00002-00 Final report April 2003

11. Endale, Kefyalew (2010). Fertilizer Consumption and Agricultural Productivity in Endale, Kefyalew (2010). Fertilizer Consumption and Agricultural Productivity in Ethiopia. Addis Ababa, Ethiopia: EDRI. 2010

12. Esteban J. Quiñones and Xinshen Diao(2012). Assessing Crop Production and Input Use Patterns in Ghana - What can we learn from the Ghana Living Standards Survey (GLSS5)? Ghana Strategy Support Program (GSSP), GSSP Working Paper No. 0024, January, 2011, International Food Policy Research Institute, Washington, DC 200061002 USA

13. European Cooperative for Rural Development (EUCORD) (2012). Rice Sector Development in East Africa, A desk study prepared for the Common Fund for Commodities, Common Fund for Commodities (CFC)

14. FAO (2014). Tanzania Country fact sheet on food and agriculture policy trends, Food and Agriculture Policy Decision Analysis available at http://www.fao.org/3/a-i4125e.pdf

15. Gregory T. and P. Sewando (2013). Determinants of the probability of adopting quality protein maize (QPM) technology in Tanzania: A logistic regression analysis, International Journal of Development and Sustainability Vol.2 No.2 (2013): 729-746

16. IFDC (2012). Tanzania Fertilizer Assessment, The African Fertilizer and Agribusiness Partnership, available at www.ifdc.org

17. Increasing, Low External-input Technology: The Case of SRI in Madagascar. Journal of Agricultural Systems, 76(3), 1085-1100. 
18. Irene S. Egyir (2007). Assessing the Factors of Use of Agro-chemicals by Plantain Farmers in Ghana Using the ASTI Analytical Framework, available in http://www.africaplatform.org/resources

19. ISSN 2319-5347, Vol. 02, No. 02, April 2013.

20. Jacob Ricker-Gilbert and T.S. Jayne (2009). Do Fertilizer Subsidies Affect the Demand for Commercial Fertilizer? An Example from Malawi, Paper prepared for presentation at the International Association of Agricultural Economists Conference, Beijing, China, August 16-22, 2009

21. Jonathan Isham (2002), The Effect of Social Capital on Fertilizer Use: Evidence from Rural Tanzania, Department of Economics Middlebury College Discussion Paper No. 0225, available http://www.middlebury.edu/ econ

22. Kadigi Reuben M. J. (2003). Rice Production Economics at the Local and National Levels: The Case of Usangu Plains in Tanzania, RIPARWIN Project, Report ELEBWU 3

23. Kenneth Baltzer and Henrik Hansen (2011) Evaluation Study Agricultural input subsidies in Sub- Saharan Africa, Institute of Food and Resource Economics, University of Copenhagen Rolighedsvej 25, 1958 Frederiksberg C., DANIDA

Mary Thuo, Boris E Bravo-Ureta, Ibrahima Hathie and Patrick Obeng-Asiedu (2014). Use of chemical fertilizer by smallholder farmers in the peanut basin of Senegal, Journal of Developing Areas Vol48 No. 1 winter, 2014

24. Lei Pan and Luc Christiaensen(2012). Who is Vouching for the Input Voucher? Decentralized Targeting and Elite Capture in Tanzania,Selected Paper prepared for presentation at the International Association of Agricultural Economists (IAAE) Triennial Conference, Foz do Iguaçu, Brazil, 18-24 August, 2012.

25. Match Maker Associates Limited (2010). Value Chain Analysis of Rice and Maize in Selected Districts in Tanzania, Study Commissioned By Agricultural Council of Tanzania(ACT) - Tanzania Agricultural Partnership Funded By EU- EC Food Facility Grant No. 2009/216-569

26. Minot Nicholas (2009), International Food Policy Research Institute, Presented at the Fertilizer Policy Symposium of the COMESA African Agricultural Markets Programme (AAMP), Livingstone, Zambia 15 June 2009

27. Minot Nicholas (2010). Staple food prices in Tanzania, Paper prepared for the COMESA policy seminar on "Variation in staple food prices: Causes, consequence, and policy options", Maputo, Mozambique, 25-26 January under the African Agricultural Marketing Project (AAMP)

28. Morris, M., V. Kelly, R. Kopicky, and D. Byerlee. 2007. Fertilizer Use in Africa: Lessons Learned and Good Practice Guidelines. Washington DC: The World Bank

29. Moser, C.M., and C. B. Barrett (2003). The Disappointing Use Dynamics of a Yield-

30. Nancy S. Padian, Madhur Gautam, Mbette Mshindo Msolla ( 2014). Enhancing Food Production and Food Security through Improved Inputs: An Evaluation of Tanzania's National Agricultural Input Voucher Scheme with a Focus on Gender Impacts, Available at http://www.3ieimpact.org/evidence/impact-evaluations/details/230/

31. Omotayo Olugbenga Alabi, Alimi Folorunsho Lawal, Ayodeji Alexander Coker and Yisau Akanfe Awoyinka (2014). Probit Model Analysis of Smallholder's Farmers Decision to Use Agrochemical Inputs in Gwagwalada and Kuje Area Councils of Federal Capital TERRITORY, ABUJA, NIGERIA, International Journal of Food and Agricultural Economics ISSN 2147-8988 Vol. 2 No. 1 pp. 85-93

32. Rios Ana R., Gerald E. Shively, and William A. Masters (2009). Farm Productivity and Household Market Participation: Evidence from LSMS Data, Contributed Paper prepared for presentation at the International Association of Agricultural Economists Conference, Beijing, China, August 16-22, 2009

33. Salami, Adeleke; Kamara, Abdul B.; Brixiova, Zuzana (2010). Smallholder Agriculture in East Africa: Trends, Constraints and Opportunities, Working Papers Series No. 105 African Development Bank, Tunis, Tunisia.

34. Tesfaye Gebre , Zerihun Mohammed, Menfese Taddesse and S. Chenchu Narayana (2013). Use of Structural Soil and Water Conservation Technologies by Small holder 
farmers in Adama Wereda, East Shewa, Ethiopia, International Journal of Advanced Structures and Geotechnical Engineering

35. Todd Benson, Stephen L. Kirama, and Onesmo Selejio (2012). The Supply of Inorganic Fertilizers to Smallholder Farmers in Tanzania, Evidence for Fertilizer Policy Development, Development Strategy and Governance Division, IFPRI Discussion Paper 01230 International Food Policy Research Institute

36. United Republic of Tanzania (URT) (2011). Mkukuta Annual Implementation Report 2010/11, Ministry of Finance, Dar es salaam, Tanzania

37. USAID/COMPETE (2010). United States Agency for International Development (USAID) and the Competitiveness and Trade Expansion Program. Staple Foods Value Chain Analysis: Country Report: Tanzania. Prepared by CHEMONICS International Inc.

38. Wayo Seini, Monty Jones, Emmanuel Tambi, and Gbadebo Odularu (2011). Input Market Initiatives that Support Innovation Systems in Africa. Accra, Ghana.

39. Wellington Jogo, Eldad Karamura, William Tinzaara, Jerome Kubiriba and Anne Rietveld (2013). Determinants of Farm-Level Use of Cultural Practices for Banana Xanthomonas Wilt Control in Uganda, Journal of Agricultural Science; Vol. 5, No. 7; 2013

40. World Bank (2012). Tanzania Agribusiness Indicators: Agriculture and Environmental Services, available at http://reliefweb.int/sites/reliefweb.int/files/resources/NonAsciiFileName0.pdf

41. Yuan Zhou, Hong Yang, Hans-Joachim Mosler and Karim C. Abbaspour(2010). Factors affecting farmers' decisions on fertilizer use: A case study for the Chaobai watershed in Northern China. The Journal of Sustainable Development Vol.4, Iss.1 (2010), Pp. 80-102. 